\title{
LISTS
}

\section{Geologic map and digital database of the San Rafael Mtn. 7.5-minute Quadrangle, Santa Barbara County, California}

By John G. Vedder ${ }^{1}$ and Richard G. Stanley ${ }^{1}$

Digital preparation by R.G. Stanley ${ }^{1}$, S.E. Graham ${ }^{2}$, and Z.C. Valin ${ }^{1}$

Pamphlet to accompany

Open-File Report 01-290

2001

This report is preliminary and has not been reviewed for conformity with the U.S. Geological Survey editorial standards. Any use of trade, product, or firm names is for descriptive purposes only and does not imply endorsement by the U.S. Government.

This database, identified as "Geologic map and digital database of the San Rafael Mtn. 7.5-minute Quadrangle, Santa Barbara County, California," has been approved for release and publication by the Director of the USGS. Although this database has been reviewed and is substantially complete, the USGS reserves the right to revise the data pursuant to further analysis and review. This database is released on condition that neither the USGS nor the U.S. Government may be held liable for damages resulting from its use.

U.S. Department of the Interior

U.S. Geological Survey

1U.S. Geological Survey, 345 Middlefield Rd., Menlo Park, CA 94025

${ }^{2}$ U.S. Geological Survey, 2255 N. Gemini Dr., Flagstaff, AZ 86001 


\section{CONTENTS}

DESCRIPTION OF MAP UNITS 3

SURFICIAL DEPOSITS 3

SEDIMENTARY ROCKS, MÉLANGE, AND SERPENTINITE 3

IGNEOUS ROCKS $\quad 8$

EXPLANATORY NOTES 9

Stratigraphic Nomenclature $\quad 9$

$\begin{array}{ll}\text { Faults } & 10\end{array}$

$\begin{array}{ll}\text { Folds } & 14\end{array}$

DIGITAL PUBLICATION AND DATABASE DESCRIPTION 14

Introduction $\quad 14$

Database Contents 15

Data Package $\quad 15$

Plot File 16

Other Files $\quad 17$

$\begin{array}{ll}\text { Software Utilities } & 17\end{array}$

How to Obtain the Digital Files 17

How to Extract the Geologic Map Database from the Tar File 17

$\begin{array}{ll}\text { Compressed Postscript Plot File } & 18\end{array}$

Portable Document (.pdf) Files 18

How to Convert the ARC/INFO Export Files 18

$\begin{array}{ll}\text { ACKNOWLEDGEMENTS } & 19\end{array}$

REFERENCES CITED 19

MAPPING CREDITS 22 


\title{
GEOLOGIC MAP AND DIGITAL DATABASE OF THE \\ SAN RAFAEL MTN. 7.5-MINUTE QUADRANGLE, SANTA BARBARA COUNTY, CALIFORNIA
}

By

\author{
John G. Vedder and Richard G. Stanley
}

2001

\section{DESCRIPTION OF MAP UNITS}

\section{SURFICIAL DEPOSITS}

Qls Landslide deposits (Holocene and Pleistocene)—Fragmentary material and soils derived from upslope and underlying rock units; arrows show direction of movement

Qya Young alluvium (Holocene and Pleistocene)—Gravel, sand, and silt along active and intermittent stream channels; commonly includes large sandstone boulders derived from Cretaceous strata; generally incised

Qoa Old alluvium (Holocene and Pleistocene)-Gravel, sand, and silt perched above stream channels or in dissected fan remnants; commonly includes very large sandstone boulders derived from Cretaceous strata; numbers indicate relative levels in areas where more than one depositional surface is discernible; levels may not correlate from place to place; at least six depositional surfaces (from youngest to oldest, Qoa1, Qoa2, Qoa3, Qoa4, Qoa5, Qoa6) preserved along lower Santa Cruz Creek near the southwestern corner of the map

\section{SEDIMENTARY ROCKS, MÉLANGE, AND SERPENTINITE}

South of Big Pine fault, South Branch-

QTpr Paso Robles(?) Formation (Pleistocene and Pliocene?)-Sandstone, conglomerate, siltstone, and mudstone, semiconsolidated to wellindurated, generally white-weathering; sandstone mostly fine- to medium-grained, silty, quartzofeldspathic; conglomerate consists largely of angular to subrounded clasts derived from Monterey Formation, and chert and sandstone derived from Franciscan Complex; nonmarine, fluvial; present southwest of Little Pine fault; thickness about $750 \mathrm{~m}$ in southwestern corner of San Rafael Mtn. quadrangle and about 1,200 $\mathrm{m}$ in adjacent Figueroa Mtn. quadrangle (Dibblee, 1966, plate 4, structure section A-A')

Tca Careaga Sandstone (Pliocene?)—Sandstone and siltstone with interbeds of pebble conglomerate and fossiliferous shell hash, white- to yellowish-weathering; thick- to very thick-bedded; sandstone quartzofeldspathic, friable to moderately hard, very fineto coarse-grained, massive to bioturbated, with locally abundant 
fossil mollusks and scattered fish scales; conglomerate beds as thick as $100 \mathrm{~cm}$, locally cross-stratified, composed mainly of wellrounded pebbles derived from Monterey Formation and Franciscan Complex; contains Pliocene(?) mollusks; shallow marine; thickness about $100-120 \mathrm{~m}$

Tm Monterey Formation (Miocene)-Northeast of Hildreth fault, mainly siliceous, calcareous, and phosphatic shale and mudstone and subordinate porcelanite and black chert, with minor beds and concretions of orange-weathering dolomite, and locally abundant, thick interbeds of sandstone; mudstone and shale are white weathering, dark brown on fresh surfaces, generally thin bedded and laminated, with locally abundant foraminifers and fish scales; at places along West Fork Santa Cruz Creek, mudstone is silty and similar in appearance to Rincon Shale of Santa Barbara coastal area; sandstone interbeds white-weathering, thin- to very thick-bedded, generally massive, normally graded in places, fine- to coarsegrained, quartzofeldspathic, with as much as 5-10 percent biotite grains, calcareous cement, locally abundant rip-up clasts of mudstone; at places along West Fork Santa Cruz Creek includes subordinate olistostromal deposits consisting of blocks up to $4 \mathrm{~m}$ long of bedded mudstone and sandstone, enclosed within poorlysorted matrix of sandy mudstone; contains upper Saucesian, Relizian, and Luisian foraminifers and zone CN 5A (middle Miocene) or lower calcareous nannofossils; bathyal marine; thickness unknown owing to complicated structure and erosion of upper contact. Southwest of Hildreth fault, mainly porcelanite and siliceous shale, generally white-weathering, brown to tan on freshly broken surfaces; generally thin-bedded and laminated with lenses and thin interbeds of black, glassy chert, but in places medium- to very thick-bedded with concretions and interbeds of limestone and orange-weathering dolomite; scattered dark brown silty and clayey interbeds; locally (as along Santa Cruz Creek in the southwestern part of the quadrangle) with lenses and thin interbeds of pelletal phosphorite; locally abundant foraminifers and fish scales; sandstone interbeds present at places but less abundant than in area northeast of Hildreth fault, generally coarse-grained, quartzofeldspathic, at places with red, gray, and green chert grains derived from Franciscan Complex and abundant fragments of molluscan and echinoid debris; contains upper Relizian and Luisian foraminifers; local intense small-scale folding, not mapped; bathyal marine; thickness uncertain owing to complicated structure but apparently about $700 \mathrm{~m}$ in along Santa Cruz Creek southwest of Little Pine fault

Tsi Unnamed sandstone (Miocene)-Inferred to be intruded into Monterey Formation along Santa Cruz Creek between Demesio Spring and Doty Cabin

Tss Unnamed sandstone (Miocene)—Sandstone and subordinate conglomerate and limestone, thick- to very thick-bedded; generally forms resistant ledges; lower part of unit generally trough cross- 
laminated and plane-laminated coarse-grained sandstone and subordinate pebble-granule conglomerate, grading upward to bioturbated medium- and fine-grained sandstone in upper part of unit; sandstone moderately to well-sorted, mostly quartzofeldspathic but in places with abundant lithic grains including chert, greenstone, graywacke, and serpentinite derived from Franciscan Complex; at places (for example, western wall of Peachtree Canyon) includes limestone composed mainly of sandsize fragments of molluscan and barnacle debris with minor amounts of quartzofeldspathic and lithic grains; locally abundant mollusks including Amussiopecten vanvlecki (Arnold), barnacles, and echinoids; these mollusks, together with a molluscan assemblage from unit Tss about $16 \mathrm{~km}$ southeast in the adjacent Little Pine Mtn. quadrangle, are probably of the "Temblor stage" of Addicott (1972); a fragment of $A$. vanvlecki from between Peachtree Canyon and Mine Canyon yielded a minimum ${ }^{87} \mathrm{Sr} /{ }^{86} \mathrm{Sr}$ age of $19.7 \pm 0.1 \mathrm{Ma}$ (R.E. Denison, Univ. of Texas at Dallas, written commun., 1999); unit restricted to southern part of quadrangle, where it rests unconformably on Espada Formation and Franciscan Complex west of the Hildreth fault and on Upper Cretaceous beds east of this fault; locally may be thin or absent, for example in the southeastern part of the quadrangle in the area between Flores Camp and Santa Cruz Guard Station; shallow marine; thickness variable, ranging from zero near Hildreth fault to about $50 \mathrm{~m}$ along Santa Cruz Creek east of Mud Spring

North of Big Pine fault, South Branch-

Th Hurricane Deck Formation of Thomas and others, 1988

(Miocene)-Sandstone and subordinate mudstone; sandstone quartzofeldspathic, generally medium- to coarse-grained, locally pebbly, thick-bedded to massive; mudstone indistinctly bedded to thin-bedded, interbedded with sandstone; unit intertongues with unnamed mudstone (unit Tmc); included in unnamed sandstone (unit Tms) by Vedder and others (1967); Fritsche and Thomas (1990) reported middle Miocene zone CN 4 calcareous nannofossils from this unit northwest of Lazaro Canyon near the western edge of the quadrangle, and Lagoe (1986) reported probable Saucesian foraminifers from the lower part of this unit about $4 \mathrm{~km}$ northwest of the northwest corner of the quadrangle; unit restricted to northern half of quadrangle; bathyal marine, deep submarine fan (Yaldezian and others, 1983)

Tmc Unnamed mudstone (Miocene)—Chiefly clayey mudstone and silty claystone, bioturbated to massive, locally concretionary, indistinctly bedded, white- to gray weathering, dark brown on fresh surfaces, locally abundant foraminifers and fish scales; includes sparse, thin-bedded, fine-grained turbidite sandstone in places; intertongues with Hurricane Deck Formation (unit Th); contains possible upper Saucesian to Luisian foraminifers and calcareous nannofossils of zones $\mathrm{CN} 3$ to $\mathrm{CN} 4$ (upper lower 
Miocene to lower middle Miocene) in outcrops near the western quadrangle edge along a Forest Service road northwest of Lazaro Canyon; contains upper Saucesian foraminifers and calcareous nannofossils possibly from near the base of zone CN 3 (upper lower Miocene) in outcrops just west of the quadrangle edge; mapped as a shale unit within either the Vaqueros Formation or the Monterey Shale by Thomas and others (1988); Popelar (1988) reported lower Saucesian foraminifers from two localities near the north edge of the map, and calcareous nannofossils of zone CN 2 (lower Miocene) from an outcrop just north of the quadrangle edge; Zemorrian assemblages from this unit reported by Vedder and others (1967) probably are Saucesian (see Explanatory Notes); unit restricted to area north of the Big Pine fault, South Branch; bathyal marine Vaqueros(?) Formation (Miocene? and Oligocene?)-Sandstone, coarse grained, locally pebbly, thick-bedded and cross-bedded, glauconitic in places; white-weathering, calcareous cement, generally a resistant ledge-forming unit; grades upward into unit Tmc; mapped as sandstone member of the Vaqueros Formation by Thomas and others (1988); included in basal part of unit Tms by Vedder and others (1967); age-diagnostic fossils have not been found in the map area; shallow marine; thickness about $30-50 \mathrm{~m}$ near northern quadrangle edge

Ts Simmler(?) Formation (Miocene? and Oligocene?)-Conglomerate, sandstone, siltstone, and mudstone, thin- to thick-bedded; sandstone and conglomerate lenticular, typically green, poorly sorted; sandstone fine- to very coarse-grained and granular, pebbly in places, cross laminated; conglomerate includes abundant pebbles, cobbles, and boulders of Cretaceous sandstone and mudstone; siltstone and mudstone typically green and red; unconformable on Upper Cretaceous strata; mapped as unnamed conglomerate and sandstone (unit Tmn) by Vedder and others (1967); mainly nonmarine (fluvial, deltaic, and estuarine?); thickness variable, 0-200 m northwest of Lazaro Canyon near western quadrangle edge and 0-150 m near northern quadrangle edge

TKs Mudstone (Paleocene? and Upper Cretaceous?)-Mudstone, micaceous, thin-bedded to indistinctly bedded, locally concretionary; includes sandstone micaceous, very thin-bedded, very fine-grained, interbedded with mudstone, at places with normal grading and partial to complete Bouma sequences; conformable on Upper Cretaceous mudstone and subordinate sandstone (unit Ksm); contains probable early Tertiary foraminifers in upper part along Coche Creek; bathyal to abyssal marine (Vedder and others, 1998); thickness unknown but perhaps about $450 \mathrm{~m}$ in axis of syncline northwest of Coche Creek

Kss Sandstone and subordinate mudstone and conglomerate (Upper Cretaceous) - Sandstone, quartzofeldspathic, micaceous, fine- to very coarse-grained, thin- to very thick-bedded, lenticular; mudstone micaceous, thin-bedded, lenticular, generally as thin 
zones in sandstone; conglomerate lenticular, containing pebble- to boulder- sized clasts, mostly of siliceous metavolcanic, granitoid, and quartzitic rocks; Popelar (1988) reports rare to sparse agglutinated and calcareous foraminifers suggestive of Late Cretaceous, probably Campanian, age from near the northern edge of quadrangle; deep marine, submarine fan deposits (Vedder and others, 1998); thickness of Upper Cretaceous strata (units Kss and Ksm combined) unknown but possibly about 2,300 m near Santa Cruz Peak

Ksm Mudstone and subordinate sandstone (Upper Cretaceous)-Mudstone, micaceous, thin-bedded to indistinctly bedded, lenticular; includes varying amounts of interbedded thinto thick-bedded sandstone; contains rare foraminifers possibly of the D2 or E zones of Goudkoff (1945) and rare, probably upper Campanian to lower Maastrichtian mollusks including Inoceramus ex gp. I. subundatus Meek and an ammonite, Glyptoxoceras? sp.; deep marine (Vedder and others, 1998)

$\mathrm{Ku}$ Sandstone, mudstone, and subordinate conglomerate, undifferentiated (Upper Cretaceous)_-Shown at places where exposures are covered or obscure and differentiation of units Kss and $\mathrm{Ksm}$ is therefore incomplete, generally on untraversed, chaparral-masked, north-facing slopes and in inaccessible deep canyons

Northeast of Hildreth fault-

Ks Sandstone and subordinate mudstone (Upper

Cretaceous)-Sandstone, quartzofeldspathic, micaceous, fine- to very coarse-grained, locally pebbly, thin-to thick-bedded and massive; mudstone partings common; thin zones of convolute bedding and dish structure at places; mudstone micaceous, indistinctly bedded, lenticular, present as thin zones interbedded in sandstone; similar in general appearance to unit Kss north of Big Pine fault, South Branch; thickness unknown but possibly about 1,300 m near eastern quadrangle edge

$\mathrm{Km} \quad$ Mudstone and subordinate sandstone (Upper Cretaceous)-Mudstone, clayey to silty, micaceous, indistinctly bedded to thin-bedded, hackly to ellipsoidal fracture, lenticular, locally concretionary; sandstone micaceous, silty, fine-grained, thin-bedded, interbedded with mudstone; similar to unit Ksm north of Big Pine fault, South Branch; contains rare, very large Inoceramus sp. similar to I. subundatus Meek, upper Campanian to Maastrichtian; contains Goudkoff D2 and D2-E foraminifers along Big Pine Road about 3 miles east of quadrangle edge (Vedder and others, 1995)

Southwest of Hildreth fault-

KJe Espada Formation of Dibblee, 1950 and 1966 (Lower Cretaceous? and Upper Jurassic) - Argillite, sandstone, and minor conglomerate, strongly fractured and overturned; includes: (1) intervals of thin- 
bedded sandstone and mudstone, sandstone generally gray to gray green and fine- to medium-grained with partial to complete Bouma sequences, convolute laminations, and ripple cross laminations, mudstone generally gray green and locally (for example, along Santa Cruz Creek near Camuesa fault) with abundant calcitic concretions; (2) intervals of thick- to very thick-bedded sandstone, medium- to coarse-grained, commonly lenticular and preserved as channel fills, locally with lenses of granule and pebble conglomerate; and (3) olistostromal(?) masses composed of sandstone blocks in sheared silty and sandy matrix; upper Tithonian Buchia spp., including B. terebratuloides (Lahusen), in two localities near Mud Spring (Wahl, 1995; W.P. Elder, written commun., 1999); plant fragments common to abundant in sandstone and mudstone beds; deep marine; thickness unknown but at least $350 \mathrm{~m}$ along southern quadrangle edge

KJf Franciscan Complex (Lower Cretaceous? and Upper Jurassic)-Mélange of tectonic origin (Wahl, 1995, 1998) consisting of blocks (mainly greenstone, chert, serpentinite, and sandstone, with minor metagraywacke, glaucophane schist, and amphibolite) dispersed in matrix of strongly sheared argillite and minor serpentinite; age based on the presence of the Valanginian fossils Buchia pacifica (Jeletzky) and Lytoceras sp. in sandstone near Redrock Canyon on the San Marcos Pass quadrangle (Schussler, 1981, p. 53), upper Tithonian Buchia sp. in sandstone along an unnamed tributary to Upper Horse Canyon on the San Marcos Pass quadrangle (Wahl, 1995), and Pliensbachian to Toarcian radiolarian assemblages in chert blocks on the San Marcos Pass and Figueroa Mtn. quadrangles (Hagstrum and others, 1996); geomorphically characterized by numerous landslides, of which only the most distinct are shown on the map

Serpentinite (Lower Cretaceous? and Upper Jurassic)—Serpentinized mantle peridotite and serpentinite matrix, in places with dispersed blocks of greenstone, chert, and amphibolite; generalized from 1:10,000-scale geologic map of Wahl (1998); apparently intrusive into rocks of the Franciscan Complex (Wahl, 1995, 1998)

\section{IGNEOUS ROCKS}

$\mathrm{Ti} \quad$ Intrusive and extrusive rocks (Miocene) - Includes (1) at least two diabase sills, each as thick as 10-15 m, intruding Monterey Formation and forming cliffs along West Fork Santa Cruz Creek near Flores Camp; (2) small diabase(?) dike intruding Monterey Formation along or near trace of Big Pine fault, South Branch, east of West Fork Santa Cruz Creek; (3) diabase sill about $20 \mathrm{~m}$ thick intruding Monterey Formation and forming cliff along hillside northeast of Black Canyon; (4) diabase dike intruding Cretaceous strata along former jeep trail about $2.5 \mathrm{~km}$ south of San Rafael Mountain; (5) white-weathering and altered volcaniclastic rock poorly exposed along ranch road west of Mine Canyon; and (6) 
fine-grained basalt yielding a whole-rock K-Ar age of $18.5 \pm 2.0 \mathrm{Ma}$ (Fritsche and Thomas, 1990) northwest of Lazaro Canyon, near the western quadrangle edge

\section{EXPLANATORY NOTES}

Geologic mapping of the San Rafael Primitive Area (now the San Rafael Wilderness) by Gower and others (1966) and Vedder and others (1967) did not include all of the San Rafael Mtn. quadrangle, and the part that was mapped was done in reconnaissance fashion. To help resolve some of the structural and stratigraphic ambiguities of the earlier mapping and to complete the mapping of the quadrangle, additional field work was done during short intervals in 1980 and 1981 and from 1996 to 1998. Contacts within the belt of Franciscan rocks at the southwestern corner of the quadrangle were generalized from the detailed map by Wahl (1998).

Because extensive areas were inaccessible owing to impenetrable chaparral, observations from several helicopter overflights $(1965,1980,1981)$ and interpretations from aerial photographs were used as compilation aids. Consequently, some of the depicted contacts and faults are highly inferential, particularly within the Upper Cretaceous rocks throughout the middle part of the quadrangle.

\section{Stratigraphic Nomenclature}

Formal stratigraphic names are not used for Upper Cretaceous and Paleocene(?) rock units. Although Dibblee (1991) applied the name Cachuma Formation to Upper Cretaceous beds throughout the San Rafael Mountains, this name may be inappropriate inasmuch as it may be preoccupied by Hall and Corbató's (1967) Carrie Creek Formation. Moreover, the type section of Dibblee's Cachuma Formation is unconformably overlain by Oligocene(?) and Miocene strata, and the upper part of the formation is not exposed in the area of the type section. There is no means of direct correlation between the strata at the top of Dibblee's type section and strata that he described as the uppermost part of the Cachuma Formation about $21 \mathrm{~km}$ to the east near Big Pine Mountain. Another difficulty is that strata on Big Pine Mountain described by Dibblee (1991) as the uppermost part of the Cachuma Formation and presumed by him to be of Late Cretaceous age are now known to include beds of Late Cretaceous, Paleocene, and early Eocene age (Vedder and others, 1998).

The contact between Upper Cretaceous mudstone and subordinate sandstone (unit Ksm) and the overlying Paleocene? and Upper Cretaceous? mudstone (unit TKs) north of the juncture of West Fork Santa Cruz Creek and Coche Creek is arbitrarily delineated in a gradational sequence. This contact is placed approximately at the top of a succession of interbedded mudstone and subordinate sandstone (map unit Ksm) that includes conspicuous, lenticular, ridge-forming sandstone zones. The overlying unit (TKs) mainly consists of a succession of mudstone and interbedded thin-bedded sandstone that extends eastward into the Big Pine Mtn. quadrangle where the unit includes the late Paleocene Sierra Blanca Limestone (Vedder and others, 1995). It is noteworthy that the Sierra Blanca apparently is absent on the San Rafael Mtn. quadrangle. 
The name Simmler(?) Formation is queried because of uncertainty in correlation with both the type Simmler in the Caliente Range and strata mapped as Simmler elsewhere in the Cuyama basin. Although these fluvial, deltaic, and estuarine(?) beds were mapped as Simmler Formation on the San Rafael Mtn. quadrangle by Popelar (1988) and by Thomas and others (1988), the stratal sequence and lithology do not resemble those in the type section. Unnamed unit Tmn of Vedder and others (1967) is the same but was not formally designated for the reasons given above.

The name Vaqueros(?) Formation (unit Tv) is queried because direct correlation with other strata mapped as Vaqueros throughout the Cuyama basin is incomplete. Additional stratigraphic work is required to be confident of usage of the name.

The unnamed mudstone unit (Tmc) that is exposed along the north edge of the quadrangle and west of Lazaro Canyon was mapped as the shale member of the Vaqueros Formation by Popelar (1988) and as a shale unit in either the Vaqueros Formation or the Monterey Shale by Thomas and others (1988) and by Fritsche and Thomas (1990). Lagoe (1986) called this unit Rincon Shale. Until a direct correlation with the type Rincon is established, use of this name may be inappropriate, even though the age may be approximately the same.

Reexamination of foraminiferan assemblages assigned to the Zemorrian by Vedder and others (1967) throughout the San Rafael Wilderness suggests that these deep-water assemblages probably are Saucesian rather than Zemorrian (R.L. Pierce, written commun., 1970).

The name Hurricane Deck Formation of Thomas and others (1988) (unit Th) is used with reservations. Because this formation, as defined, is restricted geographically and has shallow-water counterparts with other names, application of this name may not be warranted.

\section{Faults}

Fault nomenclature follows in part the usage of Nelson (1925) for the Big Pine, Little Pine, and Hildreth faults. Because the Big Pine fault apparently bifurcates on the Big Pine Mtn. quadrangle just east of the San Rafael Mtn. quadrangle, the names North Branch and South Branch are appended (Vedder and others, 1995). Big Pine fault, North Branch, seems to die out westward but may pass through or near the diabase dike along the unnamed trail on the ridge between San Rafael Mtn. and Santa Cruz Peak, and may continue from there into upper Peachtree Canyon and upper Mine Canyon. Configuration of the Big Pine fault, North Branch, suggests that this branch is northward dipping, and older strata on the north side indicate reverse displacement.

Big Pine fault, South Branch, is the same as Nelson's Cachuma fault and is a northward-dipping reverse fault from the vicinity of Black Canyon westward to Mine Canyon and beyond. Farther to the northwest, in the adjacent Figueroa Mtn. quadrangle, the Big Pine fault, South Branch, curves to a northwesterly strike and merges with the East Huasna fault zone (fig. 1). The nearly straight, linear trace of the South Branch where it parallels the south side of Coche Creek and extends northeastward into the Big Pine Mtn. quadrangle suggests a nearly vertical fault segment that links the curved, north-dipping segment of the South Branch to the North Branch. 
No piercing points (Crowell, 1959) or other unequivocal indicators of fault slip have been recognized along either of the two branches of the Big Pine fault in the San Rafael Mtn. quadrangle. Nevertheless, previous geologic

investigations along the Big Pine fault east of the San Rafael Mtn. quadrangle have yielded geologic and geomorphic evidence consistent with late Cenozoic, left-lateral displacement (Hill and Dibblee, 1953; Vedder and Brown, 1968; Vedder and others, 1973; Dibblee, 1982). Matched pairs of geologic structures that may have been contiguous prior to $13-17 \mathrm{~km}$ of left-lateral displacement along the Big Pine fault include the Nacimiento and Pine Mountain faults, the Ozena and San Guillermo faults, and the Madulce and Piedra Blanca synclines (Vedder and Brown, 1968; Vedder and others, 1973; Dibblee, 1982). Additionally, a westward onshore-offshore facies change in Eocene strata on the south side of the fault near Pine Mountain may have an offset counterpart on the north side of the fault near Madulce Peak (Vedder and Brown, 1968; Vedder and others, 1973; Dickinson, 1995). In the San Rafael Mtn. quadrangle, the stratigraphic succession in Miocene rocks north of the Big Pine fault, South Branch (see Correlation of Map Units) contrasts strikingly with Miocene rocks south of this fault, implying that significant post-Miocene displacement may have occurred along the fault.

The apparent left-lateral offsets described above may have resulted partly or entirely from late Cenozoic, left-lateral strike-slip along the Big Pine fault (e.g., Hill and Dibblee, 1953; Vedder and Brown, 1968; Dibblee, 1982). In this interpretation, the relative westward motion of the block north of the Big Pine fault may have been accommodated by oblique (left-lateral and reverse) slip along the Big Pine fault, South Branch, and may also have been accompanied by E-W directed compression and crustal shortening in the western San Rafael Mountains, including folding and reverse slip along the East Huasna and Little Pine fault zones. The latter interpretation assumes that crustal blocks adjacent to the Big Pine fault have undergone little or no rotation about vertical axes.

An alternative interpretation is that the Big Pine fault constitutes the northern boundary of the western Transverse Ranges region of crustal blocks that have rotated approximately 90 degrees clockwise about vertical axes (Whidden, 1995; Dickinson, 1995, 1996). This interpretation, however, is difficult to reconcile with paleomagnetic evidence for clockwise crustal block rotations in the Cuyama Valley area north of the Big Pine fault (Johnson and others, 1979; Ellis and others, 1993; Wilson, 1993; Dickinson, 1996; McCardel and others, 1997; McCardel and Prothero, 1997). Moreover, it should be noted that paleomagnetic information from the San Rafael Mountains and nearby areas is incomplete, and the actual extent of rotated areas is therefore uncertain. Paleomagnetic data indicate at least $77^{\circ}$ of clockwise rotation of Eocene strata at a locality in the southeastern San Rafael Mountains about $20 \mathrm{~km}$ southeast of the San Rafael Mtn. quadrangle (Whidden, 1995), but no other paleomagnetic results have been reported from elsewhere in the San Rafael Mountains.

Some regional geologic maps (for example, Jennings, 1997) depict the Big Pine fault as extending continuously from the San Rafael Mountains on the west to a junction with the San Andreas fault on the east. However, new mapping in the Lockwood Valley area about $50 \mathrm{~km}$ east of the San Rafael Mtn. quadrangle (Minor and Kellogg, 1997) indicates that the Big Pine fault does not extend to the San Andreas fault but instead merges eastward with the San Guillermo fault and then dies out in an area about $15 \mathrm{~km}$ south of the San Andreas fault. This new 
interpretation appears to be inconsistent with the suggestion, noted above, that the Ozena and San Guillermo faults were contiguous prior to left-lateral displacement along the Big Pine fault. It is noteworthy that Minor and Kellogg (1997) interpret the eastern segment of the Big Pine fault as a south-dipping, north-directed thrust fault, whereas the western segment of the Big Pine fault in the San Rafael Mtn. quadrangle is a north-dipping, south-directed reverse fault. This apparent discrepancy is unresolved but suggests that the Big Pine fault may be a complicated system of individual faults or fault segments rather than a single, laterally continuous structure.

The Camuesa fault of Dibblee (1966) is thought by us to be primarily a pre-Miocene feature that separates rocks of the Franciscan Complex (unit KJf) from the Espada Formation of Dibblee $(1950,1966)$ (unit KJe). The Camuesa fault is exposed along the northwest side of Santa Cruz Creek near Demesio Spring, where it is a sharp, subplanar surface (strike about $\mathrm{N} 35^{\circ} \mathrm{W}$, dip about $20-25^{\circ}$ SW) that separates strongly sheared sandstone and serpentinite of the Franciscan Complex on the southwest from strongly sheared argillite and sandstone of the Espada Formation on the northeast.

The map and cross sections of Dibblee (1966) depict the Camuesa fault as a northwest-striking and vertical to steeply-dipping fracture that, from near Mud Spring to the western quadrangle edge, separates Franciscan rocks on the southwest from Miocene rocks on the northeast. However, our mapping in this same area indicates that the Franciscan Complex and associated serpentinite are overlain in unfaulted, depositional contact by the unnamed Miocene sandstone (unit Tss). Map relations and field measurements indicate that the depositional contact of the unnamed Miocene sandstone on the Franciscan dips to the northeast at angles ranging from less than $30^{\circ}$ to more than $80^{\circ}$. A small segment of this depositional contact is exposed in an outcrop along the creek in Mine Canyon. At this locality, the stratigraphically lowest part of the unnamed Miocene sandstone unit is a one-meter-thick pebble and granule conglomerate that contains abundant rounded serpentinite clasts; this conglomerate rests in sharp depositional contact on serpentinite, and grades upward over a few centimeters to very hard, medium to coarse quartzofeldspathic sandstone.

Our mapping suggests that the Camuesa fault, where it separates the Franciscan Complex from the Espada Formation in the southern part of the quadrangle, is truncated by an angular unconformity at the base of the unnamed Miocene sandstone unit. This suspected truncation is covered by landslide deposits in the area between Peachtree Canyon and Mud Spring. The inferred erosional truncation of the Camuesa fault implies that most of the displacement along the fault occurred prior to deposition of the unnamed Miocene sandstone unit about $20 \mathrm{Ma}$. The exact timing of large-scale movement along the Camuesa fault is unknown, but the meandering trace of the fault in the mapped area suggests that it may be a very old structure that was folded by one or more subsequent episodes of deformation.

Also uncertain are the amount and sense of displacement on the Camuesa fault, but regional stratigraphic relationships offer some clues. In the Stanley Mountain area about $60 \mathrm{~km}$ northwest of Mud Spring, the Espada Formation is part of a conformable stratigraphic sequence that rests in depositional contact on the Jurassic Coast Range ophiolite, which in turn is in fault contact with the Franciscan Complex (Brown 1968a, b; Vedder and others, 1989). In the Demesio 
Spring area, the Coast Range ophiolite is absent, and the Espada Formation is in direct contact with the Franciscan Complex along the Camuesa fault. The absence of the ophiolite (and perhaps the lower part of the Espada Formation) along the Camuesa fault in the Demesio Spring area suggests, but does not prove, that displacement along the fault may be several hundred meters or more. Dibblee (1966) said that right-lateral displacement has occurred along the Camuesa fault, but the basis for his statement is unclear. To the best of our knowledge, no piercing points or other kinematic indicators have been recognized along the Camuesa fault.

The Little Pine fault is a northwest-striking and northeast-dipping reverse fault that, in the San Rafael Mtn. quadrangle, places rocks of the Franciscan Complex on the northeast side of the fault above vertical to overturned Miocene strata on the southwest side. About $2 \mathrm{~km}$ west of the western quadrangle edge, the Little Pine fault places the Franciscan Complex directly above steeplydipping strata of the Pleistocene and Pliocene(?) Paso Robles(?) Formation (Dibblee, 1966; Hall, 1981a). The precise amount of vertical displacement along the Little Pine fault is unknown but probably is several hundred meters or more (Dibblee, 1966). Dibblee (1966) and Hall (1981b) suggested that right-lateral movement may have occurred along the fault, but no piercing points or other potential indicators of strike-slip have been recognized, and the magnitude and sense of strike-slip displacement, if any, on the Little Pine fault are unknown.

The mapped trace of the Hildreth fault suggests that it is nearly vertical. Cretaceous and Miocene strata (units Ks, Tss, and Tm) on the northeast side of the Hildreth fault have been displaced upward relative to Miocene strata (unit $\mathrm{Tm}$ ) on the southwest side. The amount of vertical displacement along the fault is uncertain but may be several hundred meters or more. Dibblee (1966) depicted the Hildreth fault as a right-lateral strike-slip fault, but the basis for his interpretation is unclear, and the amount of strike-slip offset, if any, along the Hildreth fault is unknown. However, it may be significant that sandstone interbeds in the Monterey Formation are generally thicker, more abundant, and coarser-grained on the northeast side of the Hildreth fault than on the southwest side of the fault; and that the Monterey northeast of the fault has yielded Saucesian, Relizian, and Luisian foraminiferan faunas, whereas the Monterey on the southwest has yielded only upper Relizian and Luisian faunas. These apparent contrasts in Miocene facies and biostratigraphy across the Hildreth fault may have resulted from kilometers of thrusting and (or) strike-slip motion along the fault. Alternatively, displacement along the Hildreth fault may be relatively minor, and the differences in Miocene facies and biostratigraphy may instead reflect variations in local Miocene paleogeography (e.g., distance from a delta or other source of coarse siliciclastic sediment) that are entirely unrelated to the Hildreth fault. Our mapping in Black Canyon suggests that the Hildreth fault is truncated by the Big Pine fault, South Branch, but the intersection of the two faults is covered by Quaternary old alluvium (unit Qoa) and truncation cannot be unequivocally demonstrated.

Most of the northward-striking faults that cut Upper Cretaceous strata in the central and northern part of the quadrangle are small, high-angle normal faults with dip separations of less than $30 \mathrm{~m}$. Many of the inferred faults that transect the broad crest of Mission Pine anticline east of San Rafael Mtn. are based upon interpretation of aerial photographs and are believed to be small, 
nearly vertical normal faults. Some of these features, however, may be fracture zones with little or no offset, or very large joints.

\section{Folds}

Mission Pine anticline (Gower and others, 1966; Vedder and others, 1967) is a large, broad, eastward-plunging fold that extends from the vicinity of San Rafael Mtn. to the east edge of the quadrangle and beyond. The exact position of the crest of the Mission Pine anticline is obscure where it lies within the multiple, slightly tilted fault blocks in which measured dips are sparse. This anticline apparently dies out north of the small syncline at McKinley Mtn.

Northward dips in the Upper Cretaceous and Miocene strata along the north edge of the quadrangle reflect a short segment of the south limb of the Hurricane Deck syncline (Gower and others, 1966; Vedder and others, 1967), a large, persistent structure that extends more than $30 \mathrm{~km}$ northwestward of the quadrangle. The syncline in Upper Cretaceous rocks at the northeastern corner of the map presumably represents a southeastward extension of the Hurricane Deck syncline that continues eastward onto the Big Pine Mtn. quadrangle.

West of Peachtree Canyon in the footwall block of the Big Pine fault, South Branch, the Monterey Formation is folded into an unnamed, laterally persistent syncline that extends westward onto the adjacent Figueroa Mtn. quadrangle. The axis of this syncline strikes NW, generally parallel to the Big Pine fault, South Branch. The northern limb of the syncline is overturned and more steeply dipping than the southern limb. This syncline may have formed during southward-directed reverse displacement along the Big Pine fault, South Branch.

Southeast of Peachtree Canyon, the Monterey Formation is folded into numerous NW-striking anticlines and synclines. The axes of some of these folds are traceable laterally on aerial photographs for 2-3 kilometers, but most can be followed for only a few hundred meters or less. Many outcrops of the Monterey Formation display numerous smaller folds that are too small to show at map scale.

\section{DIGITAL PUBLICATION AND DATABASE DESCRIPTION}

\section{Introduction}

The results of this mapping are presented as a digital geologic map database. This section describes the types and general contents of files comprising the database. Information is also provided on how to extract and plot the map.

The database package includes (1) ARC/INFO (Environmental Systems Research Institute, http:/ / www.esri.com) version 8.0.2 coverages and associated tables, (2) a Portable Document Format (.pdf) file of this explanatory pamphlet, srm_expl.pdf, (3) a text file of this pamphlet, srm_expl.txt, (4) a Postscript plot file of the geologic map, Correlation of Map Units, and List of Map Units on a single sheet, srm.ps.gz, and (4) a text file that includes all metadata for the report, srm_met.txt. 


\section{Database Contents}

The files constituting the geologic map database of this report are listed below along with the interchange files from which they are extracted.

\section{Data Package}

All files listed below are in a compressed tar file named srm.tar.gz (12 $\mathrm{MB})$; see section below titled SOFTWARE UTILITES.

\begin{tabular}{|c|c|c|}
\hline $\begin{array}{l}\text { ARC/INFO } \\
\text { Interchange files } \\
\end{array}$ & $\begin{array}{l}\text { San Rafael Mtn. } \\
\underline{\text { coverages }}\end{array}$ & $\underline{\text { Contains }}$ \\
\hline srm_geo.e00 & srm_geo & $\begin{array}{l}\text { Contacts, faults, } \\
\text { geologic units, } \\
\text { and map } \\
\text { boundaries }\end{array}$ \\
\hline srm_str.e00 & srm_str & Folds and attitudes \\
\hline srm_anno.e00 & srm_anno & $\begin{array}{l}\text { Annotation } \\
\text { Leader lines } \\
\text { (no attributes) }\end{array}$ \\
\hline srm_xsec.e00 & srm_xsec & $\begin{array}{l}\text { Cross-section line } \\
\text { Annotation } \\
\text { (no attributes) }\end{array}$ \\
\hline srm_ls.e00 & srm_ls & $\begin{array}{l}\text { Landslide arrows } \\
\text { (no attributes) }\end{array}$ \\
\hline
\end{tabular}

The directory, info/, is produced in the process of importing interchange files to ARC coverages in ARC/INFO. The San Rafael Mtn. info/ directory contains:

$\underline{\text { Feature Attribute Tables }}$

Polygon Attribute Table:

Arc Attribute Table:

srm_geo.pat

Point Attribute Table:

srm_geo.aat, srm_str.aat

srm_str.pat 
$\underline{\text { Additional tables }}$

lines.lut

polys.lut

Lookup table containing geologic line codes

struct.lut

Lookup table containing geologic unit codes

Lookup table containing structure line and point codes

$\underline{\text { Raster file* }}$

srm.tif

Resultant Image

Contains

San Rafael Mtn.

base map

Topographic base from scan of USGS

San Rafael Mtn. 7.5'

quadrangle, 1959,

photorevised 1988

srm.tfw - world file for srm.tif

*Included as reference material. For plotting purposes, the monochromatic raster scan of the topographic base was converted to grid format in ARC/INFO GRID and the color reassigned in order not to obscure the geologic data.

ASCII text file

srm_expl.txt

This document

The following interchange files of the respective symbol sets used to plot the full geologic map sheet:
sanraf.lin.e00
Line set
sanraf.mrk.e00
Marker set
sanraf.shd.e00
Shade set

\section{Plot File}

The plot file is a Postscript file of the geologic map (see section below titled Software Utilities for additional information).

$$
\begin{aligned}
& \text { srm.ps.gz Geologic map, Correlation of Map Units, and List of } \\
& \text { Map Units }
\end{aligned}
$$

The file srm.ps.gz is a compressed UNIX file requiring gzip to uncompress it. Uncompressed, it will plot a 1:24,000 scale, full color geologic map of the San 
Rafael Mountain quadrangle on the topographic base. The plot is $36 \times 33$ inches in size. The plot is best reproduced on a large-format plotter at $600 \mathrm{dpi}$ or greater.

\title{
Other Files
}

\author{
srm_expl.pdf This document; .pdf file \\ srm.pdf Geologic map, Correlation of Map Units, and List of \\ Map Units; .pdf file \\ srm_met.txt $\quad$ Federal Geographic Data Committee (FGDC) \\ compliant metadata file derived from the digital \\ database; plain text file
}

\section{Software Utilities}

Files which have the gz file extension were compressed using gzip. Gzip utilities are available free of charge via the internet at the gzip home page, http:// www.gzip.org.

The data package is additionally bundled into a single tar (tape archive) file. The individual files must be extracted using a tar utility, available free of charge via the internet through links on the Common Internet File Formats page, http:// www.matisse.net/ files/ formats.html. One such utility is WinZip, available at http:// www.winzip.com (WinZip can also decompress files).

\section{How to Obtain the Digital Files}

The export files, and subsequently the geologic map database, and the plot files constituting this report may be obtained in two ways, both over the Internet.

1. The files can be obtained via the Web from Western Region Geologic Information Server. Go to the web page at http://geopubs.wr.usgs.gov/ open-file/ of 01-290 and follow the directions to download the files.

2. The files can also be obtained by anonymous ftp over the Internet from geopubs.wr.usgs.gov. The files are located in the directory / pub/openfile/of01-290. Be sure to use binary transfer mode.

Note: .e00 files are best transferred using ascii mode.

\section{How to Extract the Geologic Map Database from the Tar File}

After downloading the files, they must be uncompressed using a gzip utility such as gzip itself or WinZip. The data files must then be extracted using the appropriate tar utility. For example, in a UNIX system:

To do this

Uncompress

srm.tar.gz
Type this at the UNIX command prompt gzip -d srm.tar.gz (or use gzip utility of choice) to srm.tar 
Extract the srm/ directory from the tar file $\operatorname{tar}-\mathrm{xvbv}$ srm.tar (or use tar utility of choice)

This process will create a directory, srm/, that contains the ARC/INFO interchange files and supporting files. The directory should contain the following files:

$$
\begin{aligned}
& \text { srm_geo.e00 } \\
& \text { srm_str.e00 } \\
& \text { srm_ls.e00 } \\
& \text { srm_xsec.e00 } \\
& \text { srm_anno.e00 }
\end{aligned}
$$

The following are not included in the database tar file, and are downloaded separately:

$$
\begin{aligned}
& \text { srm.pdf } \\
& \text { srm.ps.gz } \\
& \text { srm_expl.pdf } \\
& \text { srm_met.txt }
\end{aligned}
$$

\section{Compressed Postscript Plot File}

The Postscript plot file has also been compressed using gzip. When uncompressed, the plotfile is a $300 \mathrm{MB}$ file, srm.ps; gzip uncompression is described above. For example, on a UNIX system, the plotfile can be uncompressed by typing gzip -d srm.ps.gz (or using the gzip utility of choice).

\section{Portable Document (.pdf) Files}

The .pdf files are accessed using Adobe Acrobat Reader software, available free from the Adobe website http:// www.adobe.com or other pdf compatible software. Follow instructions at the website to download and install the software. Acrobat Reader contains an on-line manual and tutorial.

\section{How to Convert the ARC/INFO Export Files}

The ARC interchange (.e00) files are converted to ARC coverages using the ARC command IMPORT with the appropriate <option>.

From the ARC command line type:

import <option> <interchange_file><output>

e.g., import cover srm_geo srm_geo 
ARC interchange files can also be read by some other Geographic Information Systems, including ArcView (ESRI) and MapInfo (http:/ / www.mapinfo.com). Please consult your GIS documentation to see if you can use ARC interchange files and the procedure to import them.

\section{ACKNOWLEDGEMENTS}

We thank the United States Department of Agriculture, U.S. Forest Service, for facilitating access to remote parts of the Los Padres National Forest, and the owners and employees of Rancho San Fernando Rey for providing access to private lands. We also thank R.E. Denison (University of Texas at Dallas) for providing a strontium isotopic age on shell material from the unnamed Miocene sandstone (unit Tss); Scott Graham, Zenon Valin, and Todd Fitzgibbon (U.S. Geological Survey, Menlo Park) for assisting with digital preparation of the map; Robert G. Bohannon (U.S. Geological Survey, Menlo Park) and Scott A. Minor (U.S. Geological Survey, Denver, CO) for technical reviews; Russell Graymer for digital review; and Paul Stone (U.S. Geological Survey, Menlo Park) for suggestions that improved the clarity of the map and accompanying materials.

\section{REFERENCES CITED}

Addicott, W.O., 1972, Provincial middle and late Tertiary molluscan stages, Temblor Range, California, in Stinemeyer, E.H., ed., Proceedings of the Pacific Coast Miocene Biostratigraphic Symposium, March 9-10, 1972, Bakersfield, Calif.: Pacific Section, Society of Economic Paleontologists and Mineralogists, p. 1-26.

Brown, J.A., 1968a, Probable thrust contact between Franciscan formation and Great Valley sequence northeast of Santa Maria, California [abs.]: Geological Society of America Special Paper 115, p. 313-314.

- 1968b, Thrust contact between Franciscan group and Great Valley sequence northeast of Santa Maria, California: Los Angeles, University of Southern California, Ph.D. thesis, $234 \mathrm{p}$.

Crowell, J.C., 1959, Problems of fault nomenclature: American Association of Petroleum Geologists Bulletin, v. 43, no. 11, p. 2653-2674.

Dibblee, T.W., Jr., 1950, Geology of southwestern Santa Barbara County, California: California Division of Mines Bulletin 150, 95 p. 1966, Geology of the central Santa Ynez Mountains, Santa Barbara County, California: California Division of Mines and Geology Bulletin 186, 99 p. 1982, Geology of the Alamo Mountain, Frazier Mountain, Lockwood Valley, Mount Piños, and Cuyama badlands areas, southern California, in Fife, D.L., and Minch, J.A., eds., Geology and mineral wealth of the California Transverse Ranges: Santa Ana, Calif., South Coast Geological Society, Inc., Annual Symposium and Guidebook 10, p. 57-77. 
1991, Geology of the San Rafael Mountains, Santa Barbara County, in Lewis, Lavon, and others, eds., Southern Coast Ranges: Santa Ana, Calif., South Coast Geological Society, Inc., Annual Field Trip Guidebook, v. 19, p. 3-31.

Dickinson, W.R., 1995, Paleogene depositional systems of the western Transverse Ranges and adjacent southernmost Coast Ranges, California, in Fritsche, A.E., ed., Cenozoic paleogeography of the western United States-II: Pacific Section, SEPM (Society for Sedimentary Geology), Book 75, p. 5384.

1996, Kinematics of transrotational tectonism in the California Coast Ranges and its contribution to cumulative slip along the San Andreas transform fault system: Geological Society of America Special Paper 305, $46 \mathrm{p}$.

Ellis, B.J., Levi, Shaul, and Yeats, R.S., 1993, Magnetostratigraphy of the Morales Formation-late Neogene clockwise rotation and compression in the Cuyama basin, California Coast Ranges: Tectonics, v. 12, no. 5, p. 11701179.

Fritsche, A.E., and Thomas, G.D., 1990, New early Miocene K-Ar date for basalt in the Hurricane Deck Formation, central Santa Barbara County, California [abs.]: Geological Society of America Abstracts with Programs, v. 22, no. 3, p. 23-24.

Goudkoff, P.P., 1945, Stratigraphic relations of Upper Cretaceous in the Great Valley, California: American Association of Petroleum Geologists Bulletin, v. 29, no. 7, p. 956-1007.

Gower, H.D., Vedder, J.G., Clifton, H.E., and Post, E.V., 1966, Mineral resources of the San Rafael Primitive Area, California: U.S. Geological Survey Bulletin 1230-A, p. A1-A28.

Hagstrum, J.T., Murchey, B.L., and Bogar, R.S., 1996, Equatorial origin for Lower Jurassic radiolarian chert in the Franciscan Complex, San Rafael Mountains, southern California: Journal of Geophysical Research, v. 101, no. B1, p. 613-626.

Hall, C.A., Jr., 1981a, Map of geology along the Little Pine fault, parts of the Sisquoc, Foxen Canyon, Zaca Lake, Bald Mountain, Los Olivos, and Figueroa Mountain quadrangles, Santa Barbara County, California: U.S. Geological Survey Miscellaneous Field Studies Map MF-1285, 2 sheets, scale 1:24,000.

1981b, Evolution of the western Transverse Ranges microplate: late Cenozoic faulting and basinal development, in Ernst, W.G., ed., The Geotectonic Development of California: Englewood Cliffs, N.J., PrenticeHall, Inc., Rubey Volume 1, p. 559-582.

Hall, C.A., Jr., and Corbató, C.E., 1967, Stratigraphy and structure of Mesozoic and Cenozoic rocks, Nipomo quadrangle, southern Coast Ranges, California: Geological Society of America Bulletin, v. 78, p. 559-582.

Hill, M.L., and Dibblee, T.W., Jr., 1953, San Andreas, Garlock, and Big Pine faults, California: Geological Society of America Bulletin, v. 64, p. 443-458.

Jennings, C.W., 1977, Geologic map of California: California Division of Mines and Geology Geologic Data Map 2, scale 1:750,000. 
Johnson, Noye, Lindsay, Everett, and Opdyke, Neil, 1979, Clockwise rotation of the Cuyama badlands region, California: Geological Society of America Abstracts With Programs, v. 11, no. 7, p. 452.

Lagoe, M.N., 1986, Miocene foraminifera from the Hurricane Deck area, Santa Barbara County, California, in Davis, T.L., and Namson, J.S., eds., Geologic transect across the western Transverse Ranges: Pacific Section, Society of Economic Paleontologists and Mineralogists, Book 48, p. 33-40.

McCardel, Kristen, Prothero, D.R., and Wilson, E.L., 1997, Magnetic stratigraphy and tectonic rotation of the middle-upper Miocene Caliente Formation, Ventura County, California [abs.]: American Association of Petroleum Geologists Bulletin, v.81, no. 4, p. 690.

McCardel, Kristen J., and Prothero, Donald R., 1997, Paleomagnetism and episodic tectonic rotation of the middle-upper Miocene Caliente Formation, northern Transverse Ranges, California: Geological Society of America Abstracts With Programs, v. 29, no. 6, p. 347.

Minor, Scott A., and Kellogg, K.S., 1997, A smaller Big Pine fault--new interpretations of fault architecture in the western Transverse Ranges, southern California: Eos, v. 78, no. 46, p. F700.

Nelson, R.N., 1925, Geology of the hydrographic basin of the upper Santa Ynez River, California: University of California Publications in Geological Sciences, v. 15, no. 10, p. 327-396.

Popelar, S.J., 1988, Miocene geology of the southwestern portion of the San Rafael Wilderness, Santa Barbara County, California: Northridge, Calif., California State University, M.S. thesis, 109 p.

Schussler, S.A., 1981, Paleogene and Franciscan Complex stratigraphy, southwestern San Rafael Mountains, Santa Barbara County, California: Santa Barbara, University of California, M.A. thesis, 235 p.

Thomas, G.D., Fritsche, A.E., and Condon, M.W., 1988, Stratigraphy and depositional environments of the Hurricane Deck Formation, a new lower and middle Miocene, submarine-fan sandstone unit in the Sierra Madre and San Rafael Mountains, northeastern Santa Barbara County, California, in Bazeley, W.J.M., ed., Tertiary tectonics and sedimentation in the Cuyama basin, San Luis Obispo, Santa Barbara, and Ventura Counties, California: Society of Economic Paleontologists and Mineralogists, Pacific Section, Book 59, p. 71-86.

Vedder, J.G., and Brown, R.D., Jr., 1968, Structural and stratigraphic relations along the Nacimiento fault in the southern Santa Lucia Range and San Rafael Mountains, California, in Dickinson, W.R., and Grantz, Arthur, eds., Proceedings of conference on geologic problems of San Andreas fault system: Stanford University Publications in Geological Sciences, v. 11, p. 242-259.

Vedder, J.G., Dibblee, T.W., Jr., and Brown, R.D., Jr., 1973, Geologic map of the upper Mono Creek-Pine Mountain area, California: U.S. Geological Survey Miscellaneous Geologic Investigations Map I-752, scale 1:48,000.

Vedder, J.G., Gower, H.D., Clifton, H.E., and Durham, D.L., 1967, Reconnaissance geologic map of the central San Rafael Mountains and vicinity, Santa Barbara County, California: U.S. Geological Survey Miscellaneous Geologic Investigations Map I-487, scale 1:48,000. 
Vedder, J.G., Howell, D.G., and McLean, Hugh, 1989, Geologic map of Chimney Canyon quadrangle and part of Huasna Peak quadrangle, California: U.S. Geological Survey Open-File Report 89-161, scale 1:24,000.

Vedder, J.G., McLean, Hugh, and Stanley, R.G., 1995, Preliminary geologic map of Big Pine Mtn. quadrangle, California: U.S. Geological Survey Open-File Report 95-554, scale 1:24,000.

Vedder, J.G., Stanley, R.G., McLean, Hugh, Cotton, M.L., Filewicz, M.V., and Vork, D.R., 1998, Age and tectonic inferences from a condensed(?) succession of Upper Cretaceous and Paleogene strata, Big Pine Mountain, Santa Barbara County, California: U.S. Geological Survey Bulletin 1995-S, p. S1-S33.

Wahl, A.D., 1995, The geology of the Franciscan Complex San Rafael Mountains mélange, California: Santa Barbara, University of California, M.A. thesis, $121 \mathrm{p}$.

1998, Cenozoic deformation of the Franciscan Complex, eastern Santa Maria basin, California: U.S. Geological Survey Bulletin 1995-W, p. W1-W20.

Whidden, K.J., Lund, S.P., and Bottjer, D.J., 1995, Extension of the western Transverse Ranges zone of Cenozoic block rotations north of the Santa Ynez fault, California, in Fritsche, A.E., ed., Cenozoic paleogeography of the western United States-II: Pacific Section, SEPM (Society for Sedimentary Geology), Book 75, p. 181-192.

Wilson, E.L., 1993, Magnetostratigraphy and tectonic rotation of middle-late Miocene deposits from the north-central Transverse Ranges, California [abs.]: Geological Society of America Abstracts With Programs, v. 25, no. 5, p. 164.

Yaldezian, J.G., Popelar, S.J., and Fritsche, A.E., 1983, Movement on the Nacimiento fault in northern Santa Barbara County, California, in Andersen, D.W., and Rymer, M.J., eds., Tectonics and sedimentation along faults of the San Andreas system: Pacific Section, Society of Economic Paleontologists and Mineralogists, Book 30, p.11-15.

\section{MAPPING CREDITS}

Reconnaissance geologic mapping by H.E. Clifton, D.L. Durham, H.D. Gower, and J.G. Vedder, April-May 1965. Selective geologic mapping, including helicopter overflights, by Hugh McLean and J.G. Vedder, September 1980; September 1981. Detailed geologic mapping of Franciscan Complex by A.D. Wahl, 1990-1992. Detailed geologic mapping by R.G. Stanley and J.G. Vedder, September 1996; June, September, and October 1997. Detailed geologic mapping by R.G. Stanley, June, September, and October 1998.

Digital preparation by R.G. Stanley, S.E. Graham, and Z.C. Valin. 